\title{
Para além dos Fundamentos da Decisão Judicial: Análise Empírica da Influência do Perfil do Réu sobre a Decisão que dispensa as Audiências Obrigatórias de Conciliação e Mediação No INÍCio do Processo (ART. 334, CPC)
}

\author{
Beyond the Arguments of the Judicial Decision: Empirical \\ Analysis of the Influence of the Defendant's Profile on the \\ Decision that dispenses the Compulsory Conciliation and \\ Mediation Hearings at the Beginning of the Process (Art. 334, \\ $\mathrm{CPC})$
}

Más Allá de los Argumentos de la Decisión Judicial: Análisis Empírico de la Influencia del Perfil del Demandado en la Decisión que dispone de las Audiencias Obligatorias de Conciliación y Mediación al Comienzo del Proceso (ARt. 334, CPC)

\author{
Alexandre Moura Alves de Paula Filho* \\ José Mário Wanderley Gomes Neto**
}

\begin{abstract}
1 Introdução. 2 Referencial teórico. $2.1 \mathrm{O}$ art. 334 do cpc/15: audiência de conciliação e mediação de designação obrigatória antes da resposta do réu. 2.2 Hipóteses legais de dispensa da audiência. 2.3 Dispensa da audiência em hipóteses contra legem. 2.4 Dispensa da audiência do art. 334, CPC, por influência do perfil do litigante? iluminando a discussão com dados empíricos. 3 Metodologia da pesquisa. 3.1 Inicialmente: o corte metodológico e definição da amostra. 3.2 Distinção dos processos que versam sobre seguro dpvat a fim de evitar vieses no resultado. $3.3 \mathrm{O}$ método de análise por regressão logística. 4 Análise dos resultados. 5 Conclusões. Referências.
\end{abstract}

\footnotetext{
* Mestre e Doutorando em Direito pela Universidade Católica de Pernambuco (UNICAP). Pós-graduado em Direito Médico e da Saúde pela Faculdade de Ciências Humanas e Exatas do Sertão do São Francisco (FACESF). Advogado. Recife, PE, BR. E-mail: <adepaulafl@hotmail.com>. https://orcid.org/0000-0003-3247-8140

"Doutor em Ciência Política pela Universidade Federal de Pernambuco (UFPE). Mestre em Direito Público pela UFPE. Professor dos cursos de graduação, mestrado e doutorado na Universidade Católica de Pernambuco (UNICAP). Recife, PE, BR. E-mail: <jose.gomes@unicap.br>. http://orcid.org/0000-0002-4003-856X
} 
Para além dos fundamentos da decisão judicial: análise empírica da influência do perfil do réu sobre a decisão que dispensa as audiências obrigatórias de conciliação e mediação no início do processo (art. $334, \mathrm{CPC})$

\section{RESUMO}

Objetivo: $O$ perfil do réu influencia na dispensa das audiências previstas no art. 334, $\mathrm{CPC}$, em feitos que tramitam pelo rito do procedimento comum nas varas cíveis da comarca de Recife/PE? Alguns juízes vêm dispensando de modo contra legem essas audiências, que são, salvo poucas exceções, obrigatórias. Com esse problema de pesquisa, o objetivo geral deste trabalho é identificar se, para além das justificativas dadas pelos juízes para dispensar um ato processual quase sempre obrigatório, um fator processual que aparentemente não está relacionado à dispensa da audiência, que é o perfil do litigante, pode apresentar correlação com a não designação contra legem do ato processual em questão.

Metodologia: Para responder ao problema de pesquisa proposto, utilizou-se de metodologia empírica quantitativa, consistente em análise estatística por regressão logística, por meio da qual se testou a força da associação entre a não designação da audiência e quatro perfis de réus distinguidos pela quantidade de ações a que respondem.

Resultados: Ao testar empiricamente a hipótese de que a variação da natureza da parte ré (entre as categorias raro, eventual, contumaz e habitual) produziria variação nas chances do juiz marcar (ou não) a audiência prévia, verificou-se que, na comarca de Recife/PE, há uma tendência a designar a audiência quando há litigantes raros no polo passivo (pessoas físicas, microempreendedores individuais, microempresas e pessoas jurídicas de pequeno porte, via de regra) e há, no sentido contrário, um aumento na tendência de não designação à medida que o réu se torna mais habitual na justiça comum cível da localidade onde foi realizada a pesquisa.

Contribuições: Com este trabalho, é possível identificar que há fatores para além dos diversos mencionados nas decisões que dispensam as audiências que influenciam na decisão de não as realizar de modo contra legem. Apresentando esse dado, é possível se pensar em propostas de lege ferenda mais realistas, isto é, que considerem o comportamento judicial mediante sua verificação empírica, e não em deduções de natureza unicamente dogmática, especialmente quando a norma em questão é suscitada como potencialmente cooperativa para uma "mudança de cultura" - no caso, da litigiosidade.

Palavras-chave: Direito Processual Civil. Estudos Empíricos em Direito. Modos de elaboração da decisão judicial. Comportamento judicial. 


\section{ABSTRACT}

Objectives: The defendant's profile influences the dismissal of the hearings provided for in art. 334, CPC, in cases that go through the rite of the common procedure in the civil courts of the city of Recife/PE? Some judges have dismissed these hearings in a manner contrary to the law, which is mandatory, with few exceptions. With this research problem, the general objective of this work is to identify whether, in addition to the justifications given by the judges to dispense with an almost always mandatory procedural act, a procedural factor that apparently is not related to the dismissal of the hearing, which is the profile of the litigant, may have a correlation with the nondesignation against legem of the procedural act in question.

Methodology: To answer the proposed research problem, a quantitative empirical methodology was used, consisting of statistical analysis by logistic regression, through which the strength of the association between the non-designation of the audience and four profiles of defendants distinguished by the number of actions to be tested that respond.

Results: When empirically testing the hypothesis that variation in the nature of the defendant (between rare, occasional, recurrent and habitual) would produce variation in the judge's chances of scheduling (or not) a previous hearing, it was found that, in the city of Recife/PE, there is a tendency to designate the audience when there are rare litigants in the passive pole (individuals, individual microentrepreneurs, microenterprises and small legal entities, as a rule) and, on the contrary, there is an increase in the tendency to no designation as the defendant becomes more habitual in the common civil justice of the locality where a research was carried out.

Contributions: With this work, it is possible to identify that there are factors other than the ones mentioned in the decisions that do not designate the audiences that influence the decision not to carry them out in a way against legem. Presenting this data, it is possible to think of more realistic lege ferenda proposals, that is, that consider judicial behavior through its empirical verification, and not deductions of a purely dogmatic nature, especially when the rule in question is raised as potentially cooperative for a "change of culture" - in this case, litigation.

Keywords: Civil Procedural Law. Empirical legal studies. Decision-making process. Judicial behavior.

\section{RESUMEN}

Objetivos: El perfil del demandado influye en la desestimación de las audiencias previstas en el art. 334, CPC, en casos que pasan por el rito del procedimiento común 
Para além dos fundamentos da decisão judicial: análise empírica da influência do perfil do réu sobre a decisão que dispensa as audiências obrigatórias de conciliação e mediação no início do processo (art. $334, \mathrm{CPC})$

en los tribunales civiles del distrito de Recife / PE? Algunos jueces han desestimado contra la ley estas audiencias, que, con pocas excepciones, son obligatorias. Con este problema de investigación, el objetivo general de este documento es identificar si, además de las justificaciones dadas por los jueces para prescindir de un acto procesal casi siempre obligatorio, un factor procesal que aparentemente no está relacionado con el despido de la audiencia, que es el perfil del litigante, puede tener una correlación con la no designación contra legem del acto procesal en cuestión.

Metodología: Para responder al problema de investigación propuesto, se utilizó una metodología empírica cuantitativa, que consiste en un análisis estadístico por regresión logística, a través del cual se probó la fuerza de la asociación entre la no designación de la audiencia y los cuatro perfiles de los acusados, distinguidos por el número de acciones a tomar. que responden.

Resultados: Al probar empíricamente la hipótesis de que la variación en la naturaleza del acusado (entre las categorías rara, ocasional, recurrente y habitual) produciría variación en las posibilidades del juez de programar (o no) una audiencia previa, se encontró que, en el condado Recife / PE, se tiende a designar la audiencia cuando hay raros litigantes en el polo pasivo (personas naturales, microempresarios individuales, microempresas y pequeñas personas jurídicas, por regla general) y, por el contrario, se incrementa la tendencia a ninguna designación como imputado se hace más habitual en la justicia civil común de la localidad donde se realizó una investigación.

Aportes: Con este trabajo es posible identificar que existen factores distintos a los mencionados en las decisiones que no designan a las audiencias que influyen en la decisión de no realizarlas de manera contraria al legem. Al presentar estos datos, es posible pensar en propuestas de lege ferenda más realistas, es decir, que consideren el comportamiento judicial a través de su verificación empírica, y no deducciones de carácter puramente dogmático, especialmente cuando la regla en cuestión se plantea como potencialmente cooperativa para un "cambio de cultura", en este caso, un litigio.

Palabras clave: Derecho Procesal Civil. Estudios empíricos en derecho. Formas de preparar la decisión judicial. Comportamiento judicial.

\section{INTRODUÇÃO}

O perfil do réu influencia na dispensa das audiências previstas no art. 334, CPC, em feitos que tramitam pelo rito do procedimento comum nas varas cíveis da comarca de Recife/PE? Com esse problema de pesquisa, o objetivo geral deste trabalho é identificar se, para além das justificativas dadas pelos juízes para dispensar um ato processual quase sempre obrigatório, um fator processual que aparentemente não está 
relacionado à dispensa da audiência, que é o perfil do litigante, pode apresentar correlação com a não designação contra legem do ato processual em questão.

$\mathrm{Na}$ prática forense, costumamos encontrar diversos fundamentos nas decisões que dispensam a audiência prevista no art. 334 do CPC. Há também posicionamentos doutrinários que defendem um alargamento do rol de hipóteses de dispensa das audiências - para além daquelas previstas no §4 do dispositivo.

É raro, contudo, que se defenda (ou que o juiz explicite na fundamentação de sua decisão) que o perfil do litigante é um fator que exerce influência na decisão de marcar ou não a audiência, pois tal postura pode suscitar alegações de inconstitucionalidade por violação da isonomia ou da imparcialidade do magistrado.

A hipótese central é que há uma tendência em não designar audiências de conciliação ou sessões de mediação nos processos cíveis - ainda que esta seja obrigatória por lei - quando figura no polo passivo um litigante habitual, a exemplo de planos de saúde, seguradoras de DPVAT e bancos - hipótese formulada em razão de ser comum que esses réus adotem política de não encerramento de litígios de modo consensual no início do processo, muitas vezes, porque se beneficiam do prolongamento do tempo para a demanda ser resolvida.

Para responder ao problema de pesquisa proposto, utilizou-se de metodologia empírica quantitativa, consistente em análise estatística por regressão logística, por meio do qual se testou a força da associação entre a não designação da audiência e quatro perfis de réus distinguidos pela quantidade de ações a que respondem.

O corte metodológico foi feito da seguinte forma: avaliaram-se os feitos que tramitam sob o rito do procedimento comum (classe no PJe: procedimento comum cível), entre 18/03/2017 e 18/03/2019, autuados nas varas cíveis da cidade do Recife/PE. Dividiram-se os réus em quatro categorias, em função do número de processos no período pesquisado:

a) litigante raro (até 10 processos);

b) litigante eventual (de 11 a 99 processos);

c) litigante contumaz (de 100 a 500 processos);

d) litigante habitual (mais de 500 processos).

Com isso, é possível responder ao problema de pesquisa, indicando se há associação mais forte entre a dispensa e alguma das categorias de réu.

\section{REFERENCIAL TEÓRICO}

\subsection{O ART. 334 DO CPC/15: AUDIÊNCIA DE CONCILIAÇÃO E MEDIAÇÃO DE DESIGNAÇÃO OBRIGATÓRIA ANTES DA RESPOSTA DO RÉU}


Para além dos fundamentos da decisão judicial: análise empírica da influência do perfil do réu sobre a decisão que dispensa as audiências obrigatórias de conciliação e mediação no início do processo (art. $334, \mathrm{CPC})$

É nítida a opção do legislador do Código de 2015 em prestigiar os métodos adequados de solução dos conflitos, engendrando todo um microssistema em prol das soluções consensuais a partir do art. $3^{\circ}$, que, mormente, em seus $\S \S 2^{\circ}$ e $3^{\circ}$, insere a autocomposição no rol de normas fundamentais do Processo Civil brasileiro ${ }^{1}$. Também sem previsão semelhante no código anterior, a atuação dos mediadores e conciliadores ganha regulamentação por meio de seção própria dentro do Livro III ("dos sujeitos do processo"), que vai do art. 165 ao 175.

No procedimento comum, cuidou de prever uma audiência de tentativa de conciliação ou mediação no início do processo, antes mesmo da apresentação da resposta pelo réu. Dessa forma, criou para o magistrado o dever de designar a audiência assim que verificada a inexistência, naquele momento, de vícios formais que ensejem a extinção do processo sem resolução de mérito (havendo ou não emenda à inicial), ou não ser caso de sentença de improcedência liminar do pedido. Eis a previsão do art. 334, $\mathrm{CPC}^{2}$, objeto do presente estudo.

1 “Art. 3o Não se excluirá da apreciação jurisdicional ameaça ou lesão a direito.

$\S 1^{\circ}$ É permitida a arbitragem, na forma da lei.

$\S 2 \circ \mathrm{O}$ Estado promoverá, sempre que possível, a solução consensual dos conflitos.

$\S 30$ A conciliação, a mediação e outros métodos de solução consensual de conflitos deverão ser estimulados por juízes, advogados, defensores públicos e membros do Ministério Público, inclusive no curso do processo judicial." (BRASIL, 2015a, online).

2 "Art. 334. Se a petição inicial preencher os requisitos essenciais e não for o caso de improcedência liminar do pedido, o juiz designará audiência de conciliação ou de mediação com antecedência mínima de 30 (trinta) dias, devendo ser citado o réu com pelo menos 20 (vinte) dias de antecedência.

$\S 1^{\circ} \mathrm{O}$ conciliador ou mediador, onde houver, atuará necessariamente na audiência de conciliação ou de mediação, observando o disposto neste Código, bem como as disposições da lei de organização judiciária.

§ 2० Poderá haver mais de uma sessão destinada à conciliação e à mediação, não podendo exceder a 2 (dois) meses da data de realização da primeira sessão, desde que necessárias à composição das partes.

$\S 3^{\circ} \mathrm{A}$ intimação do autor para a audiência será feita na pessoa de seu advogado.

$\S 4 \circ$ A audiência não será realizada:

I - se ambas as partes manifestarem, expressamente, desinteresse na composição consensual;

II - quando não se admitir a autocomposição.

$\S 5^{\circ} \mathrm{O}$ autor deverá indicar, na petição inicial, seu desinteresse na autocomposição, e o réu deverá fazêlo, por petição, apresentada com 10 (dez) dias de antecedência, contados da data da audiência.

$\S 6^{\circ}$ Havendo litisconsórcio, o desinteresse na realização da audiência deve ser manifestado por todos os litisconsortes.

$\S 7^{\circ}$ A audiência de conciliação ou de mediação pode realizar-se por meio eletrônico, nos termos da lei. $\S 8^{\circ} \mathrm{O}$ não comparecimento injustificado do autor ou do réu à audiência de conciliação é considerado ato atentatório à dignidade da justiça e será sancionado com multa de até dois por cento da vantagem econômica pretendida ou do valor da causa, revertida em favor da União ou do Estado.

$\S 9 \circ$ As partes devem estar acompanhadas por seus advogados ou defensores públicos." (BRASIL, 2015a, online).

$\S 10$. A parte poderá constituir representante, por meio de procuração específica, com poderes para negociar e transigir.

$\S 11$. A autocomposição obtida será reduzida a termo e homologada por sentença.

132 • R. Opin. Jur., Fortaleza, ano 19, n. 31, p.127-153, maio/ago. 2021 
A audiência ou sessão a ser realizada será de conciliação ou mediação. Antes de distingui-las, é importante constar que são métodos autocompositivos bilaterais com os seguintes pontos em comum:

a) há a participação de um terceiro imparcial;

b) não há imposição de resultados;

c) promoção da comunicação entre os envolvidos;

d) estímulo à busca de saídas para os envolvidos;

e) exercício da autonomia privada na elaboração de opções aos impasses (TARTUCE, 2018, p. 191).

A mediação, regulamentada em lei própria, é conceituada como "a atividade técnica exercida por terceiro imparcial sem poder decisório, que, escolhido ou aceito pelas partes, as auxilia e estimula a identificar ou desenvolver soluções consensuais para a controvérsia." (art. 1, parágrafo único, da Lei 13.140/15) (BRASIL, 2015b, online).

Trata-se, de modo mais detalhado, de um método dialogal de solução ou transformação de conflitos interpessoais no qual os mediandos escolhem ou aceitam terceiro(s) mediador(es), com aptidão para conduzir o processo e facilitar o diálogo, com vistas a se construir a compreensão das vivências afetivas e materiais da disputa, migrar das posições antagônicas para que se identifiquem os interesses e as necessidades comuns, assim como as alternativas mais consistentes, de modo que, havendo consenso, seja concretizado o acordo (VASCONCELOS, 2015, p. 56). Percebe-se, desde já, que a mediação não foca diretamente no acordo entre os mediandos. $O$ escopo principal é desfazer uma comunicação ruidosa entre as partes, podendo se considerar exitoso o procedimento que conseguiu tal fim, ainda que não tenham as partes firmado formalmente um acordo.

A conciliação, por sua vez, não possui lei própria, mas é presente no ordenamento jurídico brasileiro há mais tempo que a mediação, possuindo, inclusive, previsão desde a primeira Constituição brasileira (1824) ${ }^{3}$. Para a conciliação, foca-se, prevalentemente, no acordo. Sendo mais apropriada para lidar com relações eventuais, sem vínculos anteriores, é recomendada em relações de consumo e outras relações causais, nas quais não prevalece o interesse comum de manter um relacionamento, mas, fundamentalmente, o objetivo de equacionar interesses materiais ou questões jurídicas. (VASCONCELOS, 2015, p. 60). Com isso, há uma forte tendência a um procedimento mais rápido e simples que a mediação.

Atento à importância dessa distinção para a adoção da metodologia mais adequada a cada conflito, o legislador do CPC/15 propôs uma diferenciação no art.

$\S 12$. A pauta das audiências de conciliação ou de mediação será organizada de modo a respeitar o intervalo mínimo de 20 (vinte) minutos entre o início de uma e o início da seguinte.

3 "Art. 161. Sem se fazer constar, que se tem intentado o meio da reconciliação, não se começará Processo algum.” (BRASIL, 1824, online). 
Para além dos fundamentos da decisão judicial: análise empírica da influência do perfil do réu sobre a decisão que dispensa as audiências obrigatórias de conciliação e mediação no início do processo (art. $334, \mathrm{CPC})$

165, $\$ \S 2^{\circ}$ e $3^{\circ}$, o que configura, pois, duas as diferenças colocadas pelo Código: uma que diz respeito à natureza do conflito e outra à atuação do conciliador ou mediador.

Em relação à natureza do conflito, recomenda-se a conciliação aos casos em que não houver vínculo anterior entre as partes, a exemplo das demandas consumeristas; por outro lado, a mediação é mais indicada quando há vínculo anterior entre as partes, razão por que é bastante aplicável - e tem seus melhores índices - nas demandas que envolvem o direito de família (LIMA; PELAJO, 2016, p. 225).

Já no que diz respeito à atuação, o conciliador atua sugerindo soluções para o litígio, o que não é permitido ao mediador, que se volta ao restabelecimento da comunicação dos mediandos e à identificação de seus reais interesses.

Vale ressaltar a presença do termo preferencialmente em ambos os parágrafos, o que supõe que não se trata de regra rígida de aplicação desses métodos de solução dos conflitos, podendo os operadores do direito envolvidos com o caso, considerando suas nuances, aplicar os métodos e as finalidades da mediação quando seria caso de conciliação e vice-versa ${ }^{4}$.

\subsection{HIPÓTESES LEGAIS DE DISPENSA DA AUDIÊNCIA}

Como exceção à regra da obrigatoriedade de designação da audiência ora em análise, o próprio art. 334 traz, em seu $\$ 4^{\circ}$, duas situações nas quais o juiz deve dispensar o ato: I - se ambas as partes manifestarem, expressamente, desinteresse na composição consensual; II - quando não se admitir a autocomposição.

Com isso, pode-se perceber que não se optou pela incondicional obrigatoriedade de comparecimento e participação efetiva em audiência de conciliação ou mediação prévia, mas por uma quase obrigatoriedade (VASCONCELOS, 2015, p. 103), na medida em que, para não se realizarem essas audiências, será necessário que ambas as partes manifestem, expressamente, o desinteresse na autocomposição (art. 334, § 4º, I) ou a causa não admitir a autocomposição (art. 334, § 4º, II).

Acerca da primeira hipótese, a clareza do dispositivo em relação à necessidade de que ambos peçam a dispensa da audiência inclina parte da processualística a admitir que não é lícito ao magistrado fazê-lo de modo diferente (BUARQUE; PEDRA, 2016, p. 120). Outra parte da doutrina, por seu turno, interpreta o dispositivo de outro modo:

\footnotetext{
4 "Um bom exemplo disso reside no fato de alguns fornecedores de produtos e serviços estarem buscando mediar seus conflitos - inclusive com cláusula de mediação em seus contratos - mesmo que para as demandas consumeristas seja, a priori, mais indicada a conciliação. É que, numa visão mais ampla, na qual há interesse em criar um vínculo entre consumidor e fornecedor e quando a fidelização do cliente e a geração de uma relação de confiança forem uma prioridade para além do simples acordo, a mediação pode mostrar-se mais efetiva." (POLLONI, 2018, p. 94-95).
}

134 - R. Opin. Jur., Fortaleza, ano 19, n. 31, p.127-153, maio/ago. 2021 
Apesar do emprego, no texto legal, do vocábulo "ambas", deve-se interpretar a lei no sentido de que a sessão de mediação ou conciliação não se realizará se qualquer das partes manifestar, expressamente, desinteresse na composição consensual. Basta que uma das partes manifeste sua intenção de não participar da audiência de conciliação ou de mediação para que esta não possa ser realizada. É que um dos princípios reitores da mediação (e da conciliação) é o da voluntariedade, razão pela qual não se pode obrigar qualquer das partes a participar, contra sua vontade, do procedimento de mediação ou conciliação (art. 2o, § 2o, da Lei no 13.140/2015). A audiência, portanto, só acontecerá se nem o autor nem o réu afirmarem expressamente que dela não querem participar (e o silêncio da parte deve ser interpretado no sentido de que pretende ela participar da tentativa de solução consensual do conflito) (CÂMARA, 2016, p. 201).

A posição acima é, como o próprio autor refere, uma interpretação teleológica fundamentada em um princípio (o da voluntariedade). O próprio autor, porém, deixa claro que a interpretação literal do dispositivo conduz à dispensa da audiência apenas após requerimento expresso de ambas as partes.

Nessa discussão, vale destacar o art. $2^{\circ}, \S 2^{\circ}$, da Lei de Mediação, que prevê que "Ninguém será obrigado a permanecer em procedimento de mediação". Interpretando esse dispositivo, também há quem sustente que ele havia revogado a regra da necessidade de dispensa expressa por ambos os litigantes prevista no art. 334 do CPC (MENDES; HARTMANN, 2016, p. 173).

A outra hipótese do art. 334, § 4, é quando não se admite autocomposição em relação ao direito discutido no processo. Sobre essa questão, há uma cultura enraizada no meio jurídico que defende que os direitos indisponíveis não admitem autocomposição. Boa parte da doutrina já alerta há bastante tempo para esse equívoco:

Tanto para os legisladores como para os operadores do sistema de justiça, não podem mais bastar para justificar a restrição da disposição dos direitos considerados "indisponíveis" abstratas e retóricas presunções a respeito da hipossuficiência e da incapacidade de manifestação volitiva dos seus titulares que historicamente têm justificado academicamente sua absoluta inegociabilidade (VENTURI, 2016, p. 427).

\footnotetext{
${ }^{5}$ Prova de que tal pensamento está ultrapassado são os paulatinos avanços legislativos no sentido de permitir a autocomposição de vários direitos indisponíveis. O art. 695 do CPC, que prevê a obrigatoriedade da audiência de mediação ou conciliação no procedimento de família, é um bom exemplo, pois é cediço que muitos dos direitos de família são indisponíveis. Na Lei 13.140/15 (Lei de Mediação), o art. 3o dispõe que não só o conflito que verse sobre direitos disponíveis pode ser objeto da mediação, mas também aquele sobre direitos indisponíveis que admitam transação. Nesse último caso, o $\S 2^{\circ}$ traz exigência de oitiva do Ministério Público antes da homologação judicial. Ainda na Lei de Mediação, os arts. 32 a 40 estipulam a participação de pessoas jurídicas de direito público no procedimento de mediação.
} 
Para além dos fundamentos da decisão judicial: análise empírica da influência do perfil do réu sobre a decisão que dispensa as audiências obrigatórias de conciliação e mediação no início do processo (art. $334, \mathrm{CPC})$

Dessa forma, para que se dispense a audiência do art. 334, CPC, com base no §4, II, é necessário que o juiz fundamente a decisão, não bastando alegar genericamente que se trata de direito indisponível.

Em que pese à clareza das hipóteses de dispensa previstas no art. 334, §4º́ é preciso reconhecer que elas não exaurem as possibilidades legais de não realização da audiência.

Nesse sentido, é possível dispensar a audiência por força de negócio jurídico processual ${ }^{6}$. No que se refere à ausência dessa hipótese expressa na lei, não há, via de regra, qualquer vedação para que se convencione desse modo, como se extrai da leitura do art. 190 do $\mathrm{CPC}^{7}$. Assim,

as partes poderão, quando da negociação estabelecendo a obrigatoriedade de mediação/conciliação extrajudicial prévia ao ajuizamento de ação correspondente, acordar a dispensa da audiência de mediação e conciliação obrigatória, prevista no art. 334 do CPC. Deste modo, contribuirão para a celeridade e otimização de eventual processo jurisdicional, uma vez que as tratativas de negociação já terão sido previamente realizadas sem sucesso (LIPIANI; SIQUEIRA, 2016, p. 157).

Também cabe destacar que a tentativa de mediação/conciliação anterior à oportunidade prevista no art. 334 pode se dar pela via judicial, como nos casos em que já houve audiência em procedimento de Juizados Especiais (e, posteriormente, o processo tenha sido extinto sem resolução de mérito, decidindo a parte ajuizar ação pelo procedimento comum) ou, ainda, em Processo Administrativo (Procon, por exemplo).

Portanto, se a parte interessada buscar a solução judicial fora do Juizado, não faz sentido insistir em outra audiência de conciliação, a pretexto de aplicação do art. 334 do CPC/2015. Salvo se a unidade jurisdicional estiver a aplicar a verdadeira mediação, o que até então não se tem verificado. A repetição excepcional, aqui, seria justificada pela atuação das técnicas sérias e diferenciadas da mediação. Contudo, se não houver esse preparo, a repetição é medida inútil (DI SPIRITO, 2016, online).

${ }^{6}$ É lícito, inclusive, realizar convenção processual que obste a regra do art. 334, CPC, não só se já tiverem tentado a autocomposição pela via extrajudicial, mas também se não quiserem se submeter a nenhuma tentativa de mediação/conciliação, estipulando em contrato a chamada "cláusula opt-out" (MAZZOLA, 2017, p. 259), já que, estarão fazendo o mesmo que impõe a hipótese típica de dispensa do art. 334, § 4으. I, só que de maneira prévia ao ajuizamento da ação.

7 "Art. 190. Versando o processo sobre direitos que admitam autocomposição, é lícito às partes plenamente capazes estipular mudanças no procedimento para ajustá-lo às especificidades da causa e convencionar sobre os seus ônus, poderes, faculdades e deveres processuais, antes ou durante o processo. Parágrafo único. De ofício ou a requerimento, o juiz controlará a validade das convenções previstas neste artigo, recusando-lhes aplicação somente nos casos de nulidade ou de inserção abusiva em contrato de adesão ou em que alguma parte se encontre em manifesta situação de vulnerabilidade." (BRASIL, 2015a, online).

136 • R. Opin. Jur., Fortaleza, ano 19, n. 31, p.127-153, maio/ago. 2021 
Outra situação digna de menção é quando uma das partes tem, em seu desfavor, medida protetiva, a exemplo daquela que determina a não aproximação da parte contrária ou qualquer outra ordem judicial análoga em sede de tutela específica situação de clara incompatibilidade da realização da audiência (DI SPIRITO, 2016, online), tendo em vista a exigência de que estejam presentes as partes no ato - situação que pode vir a ser repensada caso a situação prevista no $\S 7^{\circ}$ do dispositivo ("A audiência de conciliação ou de mediação pode realizar-se por meio eletrônico, nos termos da lei") em questão seja implementada no tribunal do caso.

Por fim, é de bom alvitre ressaltar o fato de o art. 334 encontrar-se dentro do título (livro I) que trata do procedimento comum, razão pela qual a sua aplicabilidade aos procedimentos especiais deve ser analisada casuisticamente, a fim de não gerar uma "desnaturação do procedimento especial, conforme o equacionamento definido pelo legislador com o escopo de promover celeridade e efetividade." (DI SPIRITO, 2016, online). É o caso, por exemplo, da ação monitória, na qual o réu é citado para cumprir o mandado de pagamento, realização (ou abstenção) do fazer ou entrega da coisa ${ }^{8}$.

\subsection{DISPENSA DA AUDIÊNCIA EM HIPÓTESES CONTRA LEGEM}

Nos feitos cíveis, a ocorrência de uma das hipóteses legais de dispensa da audiência tem sido bastante rara, principalmente porque muitos réus se utilizam da prerrogativa de não pedir a dispensa a fim de ganhar tempo para oferecer sua resposta prerrogativa que independe do interesse de conciliar ou da formulação de proposta na audiência.

Assim, alguns juízes vêm dispensando as audiências obrigatórias em situações distintas das mencionadas linhas atrás, seja aquelas previstas no $\S$ 4o do art. 334, seja aquelas que são incompatíveis ou dispensáveis por decorrência lógica. Trata-se de verdadeiros "dribles hermenêuticos", expressão alcunhada por Lenio Streck situações em que o judiciário ignora a norma prevista em um dispositivo legal válido, violando o que é elementar no direito: "uma lei ou dispositivo vigente e válido não pode ser contornada ou desviada." (STRECK, 2016, online).

Aplicando essa ideia à temática ora investigada, diversos são os dribles realizados por juízes para não aplicar o art. 334 do CPC. Mazzola (2017, p. 254-259) aponta os seguintes:

a) violação da duração razoável do processo;

b) desinteresse já manifestado pelo autor na petição inicial;

\footnotetext{
8 "Art. 701. Sendo evidente o direito do autor, o juiz deferirá a expedição de mandado de pagamento, de entrega de coisa ou para execução de obrigação de fazer ou de não fazer, concedendo ao réu prazo de 15 (quinze) dias para o cumprimento e o pagamento de honorários advocatícios de cinco por cento do valor atribuído à causa." (BRASIL, 2015a, online).
} 
Para além dos fundamentos da decisão judicial: análise empírica da influência do perfil do réu sobre a decisão que dispensa as audiências obrigatórias de conciliação e mediação no início do processo (art. $334, \mathrm{CPC})$

c) postergação do ato para outra fase processual;

d) violação do acesso à justiça;

e) distorção da expressão "sempre que possível" (art. 3º, § 2, CPC);

f) autocomposição, interesse público e direitos indisponíveis.

Para além das mencionadas acima, outras justificativas têm sido utilizadas. Uma delas é a falta de estrutura física ou de recursos humanos, quando o foro não conta com CEJUSC ou com quadro de conciliadores e mediadores (hipótese que poderia se encaixar no drible da "violação do acesso à justiça"). Outra é a constatação do juiz de que "o réu não concilia ou não costuma levar proposta de acordo", a exemplo dos processos que envolvem seguro DPVAT, nos quais muitas seguradoras apenas formulam proposta de acordo após o resultado da perícia judicial.

Desta feita, há construções doutrinárias e jurisprudenciais de justificativas para dispensar um ato processual reputado obrigatório por simples leitura de seu enunciado, em nome de princípios e valores. Em síntese, parte da doutrina tem defendido que

\footnotetext{
cabe ao juiz, ao longo de todo o procedimento, ponderar valores e princípios (busca pela autocomposição, duração razoável do processo, efetividade da tutela jurisdicional etc.), tal como permitido (rectius: imposto) pelo art. $8^{\circ}$. De acordo com o princípio da adequação, pode (deve) o juiz modificar o procedimento (atos e fases processuais), adequando-o às peculiaridades do caso concreto (adequação judicial atípica) (REDONDO, 2018, p. 268).
}

Não menos importante, constata-se ainda a dispensa da audiência sem qualquer justificativa. Em outras palavras, como se estivesse sob a égide do CPC/73, ao receber uma petição inicial sem vícios e sem causa para improcedência liminar, o despacho limita-se a um "cite-se".

\subsection{DISPENSA DA AUDIÊNCIA DO ART. 334, CPC, POR INFLUÊNCIA DO PERFIL DO LITIGANTE? ILUMINANDO A DISCUSSÃO COM DADOS EMPÍRICOS}

Muito se discute doutrinariamente - com perspectivas dogmáticas - acerca da conciliação ou mediação nos processos cíveis. Nessa senda, questiona-se a efetividade do uso de técnicas que visam à autocomposição quando se está diante dos grandes litigantes da justiça civil brasileira. Contudo, o debate estritamente teórico sobre a temática - isto é, desgarrado de observações empíricas sobre o funcionamento dos institutos como conciliação, mediação e negociação - tende a não passar de mero "exercício de futurologia”, respaldado em metodologia de análise inadequada.

Do ponto de vista legislativo, é importante frisar que não há qualquer previsão expressa no CPC/15 no sentido de permitir ao juiz dispensar o ato em razão da baixa 
probabilidade de obtenção de acordo na audiência preliminar (CABRAL, 2017, p. 161). E não é de hoje que se questiona a efetividade das tentativas de conciliação no limiar de processos cíveis.

Em 2015, foi revogada a conhecida por “audiência preliminar", disposta no art. 331 do $\mathrm{CPC} / 73^{9}$, e adotada a norma do art. 334. O modelo de audiência do código revogado consistia na tentativa de conciliação seguida de saneamento, se preciso, realizada após a fase postulatória (em regra, após a apresentação de réplica). É importante notar que, no $\$ 3^{\circ}$, havia expressa possibilidade de não designação da tentativa de conciliação caso o juiz vislumbrasse baixa probabilidade de êxito, ao prever que se passe diretamente ao saneamento "se as circunstâncias da causa evidenciarem ser improvável sua obtenção.” (BRASIL, 1973, online).

Parte da doutrina imputa a alteração legislativa ao "reconhecido sucesso das audiências de conciliação nos diversos juizados especiais do país, somado à necessidade (sociológica e jurisdicional) de se incentivarem as técnicas alternativas à jurisdição de solução de conflitos" (ABELHA, 2016, p. 471). Contudo, existem diversas diferenças entre a tentativa de conciliação prevista no procedimento de Juizados Especiais normalmente realizada em audiência una, ou seja, na qual se praticam diversos atos processuais - e a que foi prevista no CPC/15. Pelo visto, não foram feitas pesquisas empíricas que confirmassem a efetividade de uma audiência de conciliação isolada. Nesse sentido, a audiência prevista no art. 334 do CPC:

Difere, porém, do modelo dos Juizados, em que, após a realização da audiência de conciliação, realiza-se outra, a de instrução e julgamento, na qual é apresentada defesa pelo réu. Aqui, no modelo do NCPC, entre as duas audiências, a de conciliação e a de instrução e julgamento, deverão ser praticados inúmeros atos processuais, tais como: recebimento da defesa, apresentação da réplica e tréplica se necessário, saneamento do feito pelo juiz isoladamente em seu gabinete, momento no qual, inclusive, diante do que foi alegado pelas partes, deverá fixar os pontos controvertidos e deferir a produção de provas, inclusive aquelas a serem produzidas em audiência de instrução e julgamento. Nesse ponto vislumbramos um retrocesso: toda aquela atividade de saneamento e concretização do litígio, em que o juiz, dialogando

\footnotetext{
9 "Art. 331. Se não ocorrer qualquer das hipóteses previstas nas seções precedentes, e versar a causa sobre direitos que admitam transação, o juiz designará audiência preliminar, a realizar-se no prazo de 30 (trinta) dias, para a qual serão as partes intimadas a comparecer, podendo fazer-se representar por procurador ou preposto, com poderes para transigir. (Redação dada pela Lei no 10.444 , de 7.5.2002).

$\S 11^{\circ}$ Obtida a conciliação, será reduzida a termo e homologada por sentença. (Incluído pela Lei n 8.952, de 13.12.1994).

$\S 2 \circ \mathrm{Se}$, por qualquer motivo, não for obtida a conciliação, o juiz fixará os pontos controvertidos, decidirá as questões processuais pendentes e determinará as provas a serem produzidas, designando audiência de instrução e julgamento, se necessário. (Incluído pela Lei no 8.952, de 13.12.1994).

$\S 3$ o Se o direito em litígio não admitir transação, ou se as circunstâncias da causa evidenciarem ser improvável sua obtenção, o juiz poderá, desde logo, sanear o processo e ordenar a produção da prova, nos termos do $§ 2^{\circ}$. (Incluído pela Lei no 10.444, de 7.5.2002)." (BRASIL, 1973, online).
} 
Para além dos fundamentos da decisão judicial: análise empírica da influência do perfil do réu sobre a decisão que dispensa as audiências obrigatórias de conciliação e mediação no início do processo (art. $334, \mathrm{CPC})$

com as partes, fixa os pontos controvertidos e decide a respeito das provas que serão produzidas, perde seu caráter dialógico, e o princípio da cooperação, eleito como um dos princípios reitores do NCPC, é colocado de lado. (GOUVEIA, 2014, p. 34).

A esse respeito, por meio de análise quantitativa, já se constatou um baixo índice nas audiências exclusivamente de conciliação dos Juizados Especiais Cíveis do Rio de Janeiro (abaixo de 20\% em 2009) (PALETTA, 2011, p. 56). A mesma pesquisa encontrou índices de acordo significativamente superiores quando se realiza a audiência una - que concentra conciliação, instrução e julgamento no mesmo ato, para tornar mais célere o procedimento -, propondo, em sua conclusão, que se opte por este modelo, já que a realização de duas audiências acaba, muitas vezes, gerando perda de tempo, em razão da pouca utilidade da primeira audiência, unicamente de conciliação (PALETTA, 2011, p. 64).

Outro levantamento interessante é o recentemente publicado pelo Tribunal Regional Federal da 5a Região com os resultados do CEJUSC/Recife. No relatório publicado, é feita distinção entre as audiências iniciais (art. 334, CPC) e outras designadas no curso do processo. $\mathrm{O}$ percentual de acordo mensal para as audiências iniciais, de janeiro a agosto de 2019 é de, respectivamente, 18\%, 5\%, 7\%, 16\%, 25\%, $14 \%, 12 \%$ e $22 \%$. Já para as audiências realizadas em outras fases do processo, no mesmo período, é de 83\%, 66\%, 84\%, 8\%, 64\%, 64\%, 35\% e 71\%, números expressivamente superiores (PERNAMBUCO, 2019).

Também cumpre destacar a clássica constatação de que os processos cíveis possuem menor tendência de encerramento por autocomposição que, por exemplo, os de família. Nesse sentido, em pesquisa feita nas Câmaras de Conciliação, Mediação e Arbitragem (CCMA) do TJPE entre 2008 e 2009 - isto é, antes do CPC/15 -, identificou-se uma grande disparidade entre os índices de acordo dos processos de família e cíveis. Os primeiros ficaram no patamar de 46\%, enquanto os segundos, com apenas 13\% (GOMES NETO; ALVES, 2012, p. 335).

Após o CPC/15, que instituiu a audiência obrigatória antes da contestação do réu, dados do mesmo tribunal (TJPE) revelam que, nessas tentativas de autocomposição feitas no ato designado por força do art. 334, o índice de algum êxito nas audiências efetivamente realizadas ${ }^{10}$ é de 6,2\% (PAULA FILHO, 2020, p. 82).

Esses dados já colocam uma luz interessante à discussão e nos fazem questionar: seriam os grandes litigantes, réus nos processo cíveis, avessos a práticas autocompositivas no início do processo?

\footnotetext{
10"Se o dado levar em consideração as audiências designadas e frustradas por ausência de uma das partes, não validação da citação, desistência antes da audiência ou realização de acordo pelas partes antes da data da audiência, o valor cai para 4,65\%." (PAULA FILHO, 2020, p. 82).
}

140 • R. Opin. Jur., Fortaleza, ano 19, n. 31, p.127-153, maio/ago. 2021 


\section{METODOLOGIA DA PESQUISA}

\subsection{INICIALMENTE: O CORTE METODOLÓGICO E DEFINIÇÃO DA AMOSTRA}

É necessário, antes de passarmos à análise da pesquisa realizada, fazermos a delimitação metodológica no que tange a tempo, espaço, matérias e demais nuances da pesquisa $^{11}$.

Escolheu-se o período de 02 anos de ajuizamento das demandas, entre 18 de março de 2017 e 18 de março de 2019. A data inicial justifica-se por se dar exatamente um ano após a entrada em vigor do $\mathrm{CPC} / 15$, pelo que se entende ser razoável período para a organização do foro para adaptação às novidades do código vigente, notadamente, à realização das audiências preliminares.

Adotaram-se, ademais, as ações que correm pela classe judicial denominada Procedimento Comum Cível no programa do Processo Judicial Eletrônico (PJe/TJPE $1^{\circ}$ grau). Isso porque é possível que alguns magistrados divirjam sobre a aplicabilidade do instituto do art. 334, CPC, a alguns procedimentos especiais. Desta feita, considerando que o objeto da pesquisa está direcionado apenas a ações que, conforme a indicação do sistema, tramitam sob o procedimento comum (o que é chamado no âmbito do PJe de "Procedimento Comum Cível"), obtém-se um resultado mais fiel ao que se pretende investigar ${ }^{12}$.

Feitas essas considerações, temos que o Universo $(\mathrm{N})$, que corresponde a todas as demandas de "procedimento comum cível" ajuizadas nas 68 varas cíveis de Recife/PE entre 18/03/2017 e 18/03/2019, analisadas nesta pesquisa, é de 31.680 (trinta e um mil, seiscentos e oitenta) processos, como se pode verificar do Anexo $1^{13}$.

Para obter uma representação de $95 \%$ do universo pesquisado, com o intervalo de confiança (correspondente à margem de erro) em 5\%, conforme cálculo inferencial, utilizou-se a seguinte fórmula matemática $\left(n=N Z^{2} p(1-p)(N-1) e^{2}+Z^{2} p(1-p)\right)$ adotada

\footnotetext{
${ }^{11}$ Para tanto, os autores disponibilizaram dois anexos em um documento. $\mathrm{O}$ anexo $\mathrm{n}^{\circ} 1$ mostra a relação de processos por vara e quantos deles foram analisados em cada uma, de modo aleatório, após realização de sorteio. $\mathrm{O}$ anexo de $\mathrm{n}^{\circ} 2$ traz a relação de todos os processos sorteados e analisados, que formaram o conteúdo da amostra observada. Os anexos estão disponíveis em domínio público, que pode ser acessado em: https://bit.ly/2COfqkM.

${ }^{12}$ Por meio do sistema PJE, verificaram-se quantas ações da classe judicial 'Procedimento comum cível' cada uma das 34 varas cíveis (divididas em Seção A, que funciona apenas pela manhã, e Seção B, que funciona apenas à tarde) receberam no período selecionado.

${ }^{13}$ Não estão incluídas em tal universo as ações que correm em segredo de justiça, pois não ficam visíveis à consulta do advogado no sistema PJe. Contudo, é de conhecimento geral que, na seara cível, as ações que tramitam sob sigilo constituem um quantitativo muito pequeno, não prejudicando o conjunto de ações ora pesquisado.
} 
Para além dos fundamentos da decisão judicial: análise empírica da influência do perfil do réu sobre a decisão que dispensa as audiências obrigatórias de conciliação e mediação no início do processo (art. $334, \mathrm{CPC})$

como padrão internacional em estudos empíricos pelas ciências humanas, sociais e sociais aplicadas ${ }^{14}$.

Com isso, a partir da população descrita acima, chegou-se a uma amostra de 380 (trezentos e oitenta) processos. Dividindo-se esse número de processos por vara, ter-se-ia 5,59 (resultado de 380:68). Por isso, tal valor foi distribuído aleatória e proporcionalmente para o quantitativo de 6 processos em 40 varas e 5 processos em 28 varas. Realizado eletronicamente o sorteio, geraram-se 28 números entre 68 (número total de varas) $)^{15}$.

Por outro lado, os processos a serem analisados também foram escolhidos por sistema de sorteio eletrônico (se se tratava de vara com 450 processos no período pesquisado, na qual se analisaram cinco processos, sorteamos cinco casos dentre os 450 existentes).

Todos os processos que compuseram a amostra analisada foram listados no Anexo 2.

\subsection{DISTINÇÃO DOS PROCESSOS QUE VERSAM SOBRE SEGURO DPVAT A FIM DE EVITAR VIESES NO RESULTADO}

Chamou a atenção, ao longo da pesquisa, um comportamento judicial reiterado diante de processos que versam sobre uma matéria específica: pedido de seguro DPVAT. Trata-se de processos nos quais se pede indenização em virtude de Seguro Obrigatório de Danos Pessoais causados por veículos automotores de via terrestre, ou por sua carga, a pessoas transportadas ou não. A matéria está regulamentada na Lei 6.194/74.

As principais nuances desses processos que importam para esta parte do trabalho são que os valores indenizatórios são tabelados na lei, sendo o maior (em caso de morte ou invalidez permanente) de R \$ 13.500,00 (treze mil e quinhentos reais). Ademais, é imprescindível - para praticamente todos os casos - a perícia médica para que se aufira a extensão do dano e o enquadre na categoria adequada da tabela ${ }^{16}$.

\footnotetext{
${ }^{14}$ Nesta fórmula, $N$ corresponde ao tamanho da população, e à margem de erro (porcentagem no formato decimal) e $z$ ao escore $z$.

${ }^{15}$ Conforme demonstrado no Anexo 1, as varas em que serão analisados 5 (cinco) processos na Seção A são as de número: 5, 6, 7, 9, 12, 14, 16, 19, 26, 28, 29 (11 ao todo); ao passo que na Seção B são: 3, 7, $8,10,15,16,17,19,20,21,25,26,27,28,29,30,32$ (17 ao todo), equivalentes aos números sorteados após o $34^{\circ}(37,41,42,44,49,50,51,53,54,55,59,60,61,62,63,64,66)$. Por exclusão, as varas nas quais serão verificados 6 (seis) processos são, na Seção A: 1, 2, 3, 4, 8, 10, 11, 13, 15, 17, 18, 20, 21, 22, 23, 24, 25, 27, 30, 31, 32, 33, 34 (23 ao todo); e na Seção B: 1, 2, 4, 5, 6, 9, 11, 12, 13, 14, $18,22,23,24,31,33,34$ (17 ao todo).

${ }^{16} \mathrm{O}$ fundamento legal encontra-se no artigo $5^{\circ}, \S 5^{\circ}$, que reza que "O Instituto Médico Legal da jurisdição do acidente ou da residência da vítima deverá fornecer, no prazo de até 90 (noventa) dias, laudo à vítima com a verificação da existência e quantificação das lesões permanentes, totais ou parciais". (Redação dada pela Lei no 11.945 , de 2009).
}

142 • R. Opin. Jur., Fortaleza, ano 19, n. 31, p.127-153, maio/ago. 2021 
Com isso, criou-se uma praxe por parte das seguradoras de apenas fornecer proposta de acordo após a perícia. O exame médico pelo expert do juízo, então, não apenas dá subsídios ao juiz em relação à necessidade/quantificação da indenização, mas também às seguradoras sobre a viabilidade de um acordo e o valor da proposta a ser ofertada, já que, após a perícia, sendo caso de condenação, será possível saber que valor tende a ser arbitrado pelo magistrado.

Diante dessas particularidades que envolvem os processos que versam sobre Seguro DPVAT, observou-se uma acentuada resistência dos órgãos judiciais pesquisados em designar as audiências do art. 334. Via de regra, o argumento usado foi de que nada adianta designar uma audiência de conciliação se o réu possui política de não conciliar antes da perícia. Com isso, boa parte dos magistrados se utilizou do instituto da produção antecipada de prova, previsto nos arts. 381 e 382 do CPC/15, para determinar a perícia. A partir daí, alguns juízes já passavam para a contestação, ignorando por inteiro o comando do art. 334, enquanto outros marcavam a audiência para perícia e, imediatamente após o resultado, tentativa de conciliação.

Eis o provável viés de resultado: o fato de que todas as seguradoras de DPVAT que tiveram processos em trâmite nas varas cíveis se encontram no grupo X4 (acima de 500 processos no período pesquisado) somado ao percentual de cerca de $90 \%$ de não designação da audiência nesses processos, além de que essa matéria corresponde a um relevante percentual da amostra (cerca de 21\%). Aliando um dado ao outro, os processos de seguro DPVAT tendem a acentuar exacerbadamente o índice não designação da audiência para réus habituais.

Como esse padrão encontrado pode enviesar os resultados encontrados, decidiuse por fazer um novo levantamento para eventuais confrontamentos (com $\mathrm{x}$ sem os processos DPVAT), o que demandou a análise de 81 novos processos, sorteados aleatoriamente, para substituir os processos DPVAT na amostra ${ }^{17}$.

Portanto, pesquisaram-se ao todo 461 processos, sendo 380 na primeira amostra e outros 81 novos para substituir os DPVAT e constituir a segunda amostra. No Anexo 2 deste trabalho, no qual consta a listagem de todos os processos que serviram de objeto para esta pesquisa, os Processos no 381 a 461 são os que substituíram os de DPVAT na primeira amostra.

\subsection{O MÉTODO DE ANÁLISE POR REGRESSÃO LOGÍSTICA}

A metodologia adequada para responder ao problema de pesquisa em questão é

\footnotetext{
${ }^{17}$ Nessa segunda amostra, para se substituir um processo DPVAT de uma determinada vara, sorteou-se um novo processo de qualquer outra matéria, em tramitação nessa mesma vara.
} 
Para além dos fundamentos da decisão judicial: análise empírica da influência do perfil do réu sobre a decisão que dispensa as audiências obrigatórias de conciliação e mediação no início do processo (art. $334, \mathrm{CPC})$

empírica, de natureza quantitativa ${ }^{18}$. $\mathrm{O}$ método é o de análise por regressão logística que consiste em uma ferramenta de pesquisa

empregada para testar as hipóteses previstas nos diversos modelos formais, ao verificar se existe associação entre a presença, ou ausência, de variáveis extraídas dos modelos e os resultados binários esperados, baseados na referida escolha entre alternativas, de modo a indicar, no campo da probabilidade, se a presença das variáveis explicativas aumenta ou diminui as chances do evento predito ocorrer (GOMES NETO; BARBOSA; VIEIRA, 2018, p. 229).

A regressão está intimamente aliada à correlação, quando o interesse é extrair a força da associação entre duas variáveis. Especificamos uma variável como dependente e uma como independente, isto é, acredita-se que uma variável influencia a outra (LEVIN; FOX; FORDE, 2014, p. 401). Por isso, o presente trabalho tem como problema de pesquisa a indagação se o perfil do réu estaria associado ao descumprimento da norma processual, para que não se realize a audiência do art. 334, CPC, em varas cíveis do Recife/PE.

Como se pode perceber, a variável escolhida é um fator processual que pode interferir nas escolhas institucionais de seguir ou não o comando da lei. Em outras palavras, como parte dos magistrados entende que designar a audiência do art. 334 é uma escolha discricionária, testamos se a presença ou variação do tipo de réu pode interferir nesse processo decisório.

Sabemos que uma boa parcela dos réus das ações que tramitam em varas cíveis são litigantes habituais e que, conforme já explanado, também é fato notório que muitos deles têm uma política prévia de não conciliar no início do procedimento. Diante desses fatos, procuramos testar se aquele que se encontra no polo passivo pode interferir no processo de escolha do juiz entre designar ou não a audiência.

Para a obtenção da regressão logística, preencheu-se uma matriz, com variáveis independentes, relativas a cada tipo de litigante, marcadas com X1 (litigante raro - até 10 processos); X2 (litigante eventual - de 11 a 99 processos); X3 (litigante contumaz - de 100 a 500 processos), e X4 (litigante habitual - mais de 500 processos). A variável dependente (Y) corresponde à designação (preenchida com 1) ou não designação contra legem

\footnotetext{
${ }^{18} \mathrm{~A}$ pesquisa quantitativa descritiva consiste "em investigações de pesquisa empírica cuja principal finalidade é o delineamento ou análise das características de fatos ou fenômenos, a avaliação de programas, ou o isolamento de variáveis principais ou chave". Uma categoria da pesquisa quantitativa descritiva é o que se chama de "estudos de verificação de hipótese" - aqueles estudos quantitativodescritivos que contêm, em seu projeto de pesquisa, hipóteses explícitas que devem ser verificadas. Essas hipóteses são derivadas da teoria e, por esse motivo, podem consistir em declarações de associações entre duas ou mais variáveis, sem referência a uma relação causal entre elas (MARCONI; LAKATOS, 2003, p. 187).
}

144 • R. Opin. Jur., Fortaleza, ano 19, n. 31, p.127-153, maio/ago. 2021 
(preenchida com 0) da audiência ${ }^{19}$. Após o preenchimento dessa matriz, a análise foi reproduzida substituindo-se os processos sobre seguro DPVAT por outros de outras matérias.

Codificadas as informações extraídas dos casos integrantes da amostra pesquisada e preenchida a respectiva matriz, os dados serão submetidos à análise estatística por regressão logística, através de cálculos de função logarítmica relacionados às referidas variáveis. Tais cálculos são, nos dias de hoje, realizados por aplicativos de processamento de dados e de análise estatística (Microsoft Excel, SAS, SYSTAT, R, Stata, SPSS, Python, BioStat, dentre outros), cujos resultados (outputs) são apresentados através de expressões numéricas, a serem devidamente interpretadas (e compreendidas) à luz dos modelos, da teoria e das hipóteses inerentes às questões de pesquisa (GOMES NETO; BARBOSA; VIEIRA, 2018, p. 221-222).

No presente trabalho, após planilhar os dados em Excel, utilizou-se o programa SPSS para extrair a regressão logística. Assim, o programa fornece uma tabela, no seguinte modelo:

\section{B | S.E. | Wald | df | Sig. | Exp(B)}

Para a análise que se pretende fazer, dos seis valores em equação fornecida, três importam: B (coeficiente), Sig. (significância) e $\operatorname{Exp}(B)$ (razões de chance).

O coeficiente (B) diz a tendência (positiva ou negativa). Apesar de expresso em números, para essa análise apenas importa o sinal do coeficiente. Tem sua leitura associada à do exponencial para, assim, mostrar "a intensidade da associação entre a chance de se verificar a variável dependente (resposta) e a presença das variáveis independentes (explicativas)" (GOMES NETO; BARBOSA; VIEIRA, 2018, p. 222).

A significância (Sig.) demonstra a robustez do modelo para explicar a associação entre as variáveis testadas, isto é, se é cabível realizar a inferência estatística a partir dos resultados obtidos ou se tal resultado é produto, dentre diversas causas possíveis, de um viés ou de um erro amostral. Por padrões internacionais, quanto mais próximo de 0,05, melhor a explicação (GOMES NETO; BARBOSA; VIEIRA, 2018, p. 222).

No caso em tela, como algumas variáveis aparecem em poucos casos na amostra, a significância pode dar um valor alterado, embora o resultado encontrado seja importante para responder à pergunta. Em outras palavras, embora responda ao problema de pesquisa, não se tem, para aquela variável, uma quantidade sólida de dados. Em se tratando de uma seleção aleatória de casos, não é possível selecionar apenas amostras com a quantidade de casos de uma variável para robustecer a significância, sob pena de se enviesar a seleção da amostra.

${ }^{19}$ Os casos em que houve dispensa das audiências nas situações expostas no item 2.2 deste trabalho, a propósito, constituem um percentual ínfimo (inferior a 1\%) da amostra. 

decisão que dispensa as audiências obrigatórias de conciliação e mediação no início do processo (art. $334, \mathrm{CPC})$

A exponencial ou razão de chance $(\operatorname{Exp}(B))$ diz o quanto as chances do evento se alteram na presença da variável. É necessário que seja lido em conjunto com o coeficiente. Se o coeficiente é positivo, o exponencial mostra o quanto as chances aumentam, se for negativo, o exponencial mostra o quanto as chances diminuem. Se o exponencial é muito próximo a zero, significa que não existe associação entre a variável e o resultado. Assim, por exemplo, se o resultado do exponencial é 1,5 e o sinal do coeficiente é positivo, significa que o aumento de uma unidade da variável explicativa $\mathrm{X} 1$ influi positivamente num aumento de uma vez e meia nas chances de ocorrer o evento esperado (1) (GOMES NETO; BARBOSA; VIEIRA, 2018, p. 223).

\section{ANÁLISE DOS RESULTADOS}

Antes da análise dos resultados da regressão logística, dados estatísticos simples, que descrevem o possível viés de resultado mencionado no item 3.2, cabem destaque.

A explicação matemática do enviesamento que os processos de seguro DPVAT causariam no todo da amostra é ilustrada no Gráfico 1. Percebemos que, dos 380 processos analisados, 81 versavam sobre a matéria, o que corresponde a 21,3\% do todo. Desses processos, em 72 não foi designada a audiência, enquanto em apenas 9 , decidiuse por marcar a audiência após a perícia antecipada:

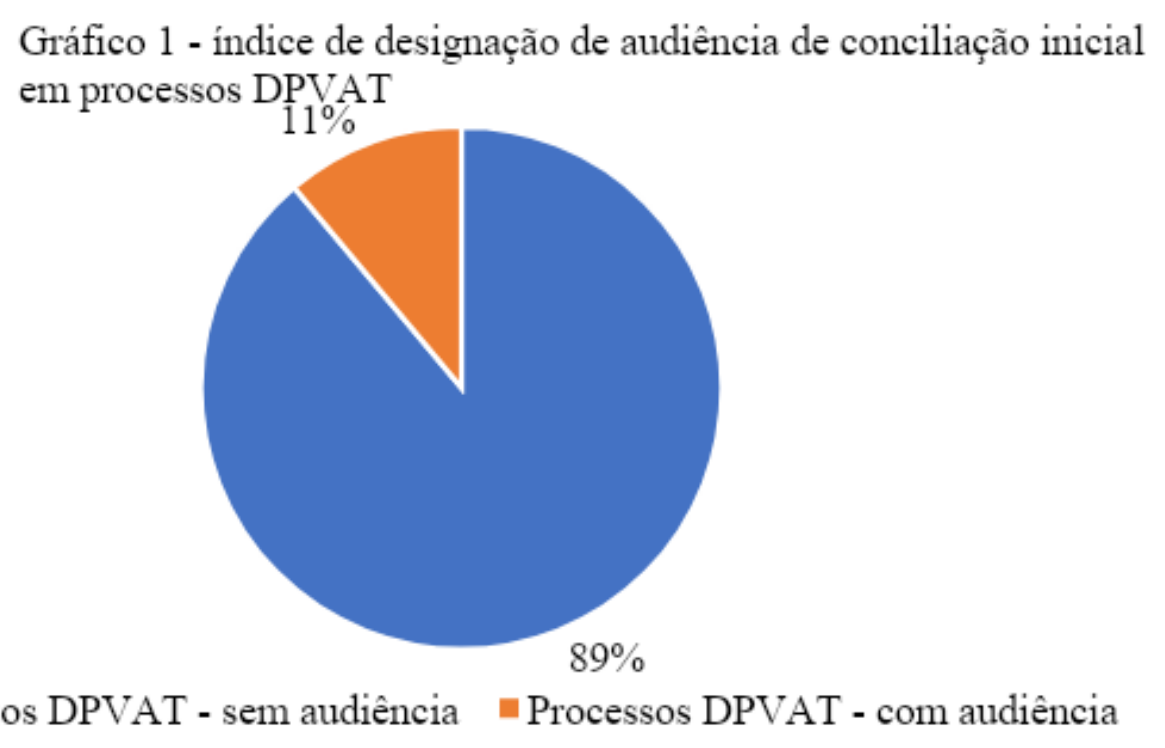

Fonte: elaboração dos autores.

O Gráfico 1 confirma a necessidade de se fazer uma análise sem englobar os processos DPVAT, porque, em razão do percentual significativo na amostra, atrelado ao resultado quase que padrão nesses casos, gera viés de resultado. Assim, conclui-se que os 
casos DPVAT em si são outro fator contra legem para a não designação da audiência. Isso ficará ainda mais claro no Gráfico 2.

Passemos à análise descritiva por regressão logística, a fim de responder ao problema de pesquisa.

Os testes feitos com variações de tipo de réu demonstram um comportamento judicial que se modifica a depender da natureza do litigante (raro/eventual/contumaz/habitual), porém não permitem inferir com precisão numérica o quanto aumentam ou diminuem as chances de que se designe o ato diante de cada uma das variáveis observadas. Vejamos os valores encontrados:

Tabela 1 - Tipo de réu - resultados da matriz 1 (amostra inicial)

\begin{tabular}{|c|c|c|c|c|c|c|}
\hline & B & S.E. & Wald & df. & Sig. & $\operatorname{Exp}(\mathrm{B})$ \\
\hline $\begin{array}{l}\mathrm{X} 1 \\
\text { (raros) }\end{array}$ & 1,43 & 0,32 & 19,84 & 1 & 0,000 & 0,24 \\
\hline \multirow[t]{3}{*}{ Constant } & 1,89 & 0,30 & 40,32 & 1 & 0,000 & 6,62 \\
\hline & & & & & & \\
\hline & $\mathrm{B}$ & S.E. & Wald & df. & Sig. & $\operatorname{Exp}(\mathrm{B})$ \\
\hline $\begin{array}{l}\mathrm{X} 2 \\
\text { (eventuais) }\end{array}$ & 0,40 & 0,35 & 1,26 & 1 & 0,262 & 0,67 \\
\hline \multirow[t]{3}{*}{ Constant } & 1,10 & 0,33 & 10,86 & 1 & 0,001 & 3,00 \\
\hline & & & & & & \\
\hline & B & S.E. & Wald & df. & Sig. & Exp(B) \\
\hline $\begin{array}{l}\mathrm{X} 3 \\
\text { (contumazes) }\end{array}$ & 1,16 & 0,50 & 5,50 & 1 & 0,019 & 0,31 \\
\hline Constant & 1,82 & 0,48 & 14,33 & 1 & 0,000 & 6,20 \\
\hline \multirow[t]{2}{*}{-----} & $=$ & & & & & \\
\hline & B & S.E. & Wald & df. & Sig. & Exp(B) \\
\hline $\begin{array}{l}\text { X4 } \\
\text { (habituais) }\end{array}$ & $-1,29$ & 0,25 & 26,84 & 1 & 0,000 & 3,63 \\
\hline Constant & 0,28 & 0,14 & 4,10 & 1 & 0,043 & 1,32 \\
\hline
\end{tabular}

Fonte: elaboração dos autores.

Tabela 2 - Tipo de réu - resultados da matriz 2 (sem processos DPVAT)

\begin{tabular}{|c|c|c|c|c|c|c|}
\hline & B & S.E. & Wald & df. & Sig. & Exp(B) \\
\hline $\begin{array}{l}\mathrm{X} 1 \\
\text { (raros) }\end{array}$ & 0,65 & 0,32 & 4,06 & 1 & 0,044 & 1,92 \\
\hline \multirow[t]{3}{*}{ Constant } & 1,38 & 0,16 & 79,32 & 1 & 0,000 & ,398 \\
\hline & & & & & & \\
\hline & $\mathrm{B}$ & S.E. & Wald & df. & $\begin{array}{l}\text { Sig. } \\
\end{array}$ & Exp(B) \\
\hline $\begin{array}{l}\mathrm{X} 2 \\
\text { (eventuais) }\end{array}$ & $-0,49$ & 0,35 & 1,94 & 1 & 0,163 & 0,61 \\
\hline \multirow[t]{3}{*}{ Constant } & 1,64 & 0,15 & 119,25 & 1 & 0,000 & 5,15 \\
\hline & & & & & & \\
\hline & $\mathrm{B}$ & S.E. & Wald & df. & Sig. & Exp(B) \\
\hline $\begin{array}{l}\mathrm{X} 3 \\
\text { (contumazes) }\end{array}$ & $-0,20$ & 0,4 & 0,25 & 1 & 0,620 & 0,82 \\
\hline \multirow[t]{3}{*}{ Constant } & 1,58 & 0,15 & 118,77 & 1 & 0,000 & 4,88 \\
\hline & & & & & & \\
\hline & $\mathrm{B}$ & S.E. & Wald & $\mathrm{df}$. & Sig. & Exp(B) \\
\hline $\begin{array}{l}\text { X4 } \\
\text { (habituais) }\end{array}$ & $-0,10$ & 0,27 & 0,14 & 1 & 0,706 & 0,9 \\
\hline Constant & 1,61 & 0,19 & 71,27 & 1 & 0,000 & 5,00 \\
\hline
\end{tabular}

Fonte: elaboração dos autores. 
Para além dos fundamentos da decisão judicial: análise empírica da influência do perfil do réu sobre a decisão que dispensa as audiências obrigatórias de conciliação e mediação no início do processo (art. $334, \mathrm{CPC})$

Analisando a variação do tipo de réu, é perceptível uma tendência de designar as audiências quando há litigantes raros/eventuais no polo passivo e de não se marcar o referido ato em se tratando de litigantes contumazes/habituais, conforme se observa no Gráfico 2:

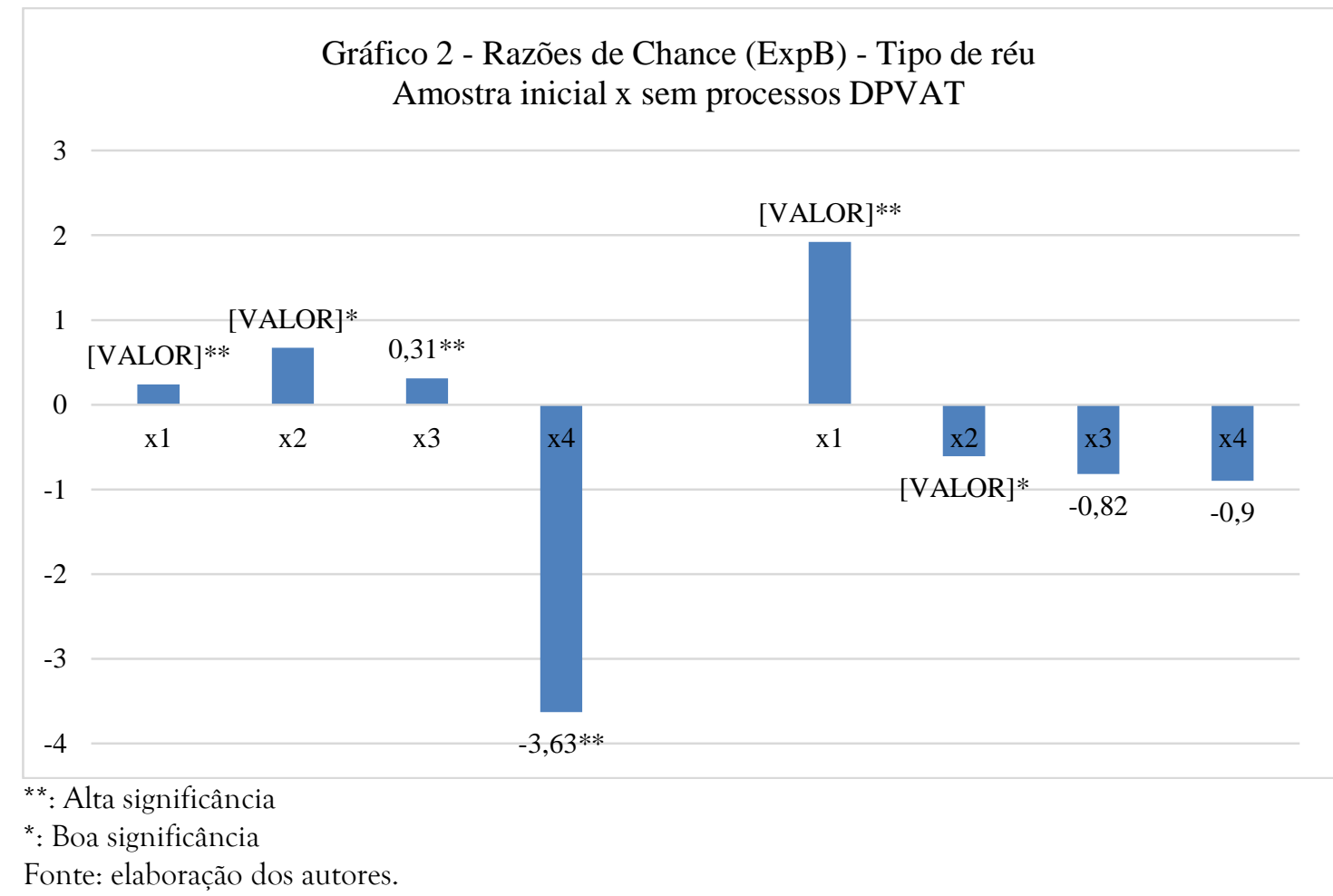

Analisando a parte esquerda do gráfico (amostra inicial), há maior tendência, com elevada significância nos valores obtidos, de não designação da audiência diante de réus habituais (mais de 500 processos no período pesquisado). Na presença desses réus, a chance de não ser marcado o ato diminuiu 3,63 vezes. No entanto, nessa amostra, a conduta reiterada adotada pelos magistrados diante de processos que versam sobre seguro DPVAT gerou um viés de resultado. Isso porque todas as seguradoras de DPVAT que foram rés nos processos pesquisados se encontram na categoria $\mathrm{x} 4$ (litigantes habituais).

Retirando-se os processos que versam sobre seguro DPVAT, os valores de $\mathrm{x} 2$ (réus eventuais) e x3 (réus contumazes) caíram, passando a expressar uma redução de chances de designação da audiência, contudo x1 (réus raros) sofreu um aumento considerável e x4 (réus habituais), uma redução.

Com a exclusão dos processos DPVAT e entrada de 81 outros novos, com diferentes litigantes, e sem que se possa estabelecer uma postura constante por parte dos juízes, como sói ocorrer nos processos excluídos, obtivemos como resultado uma tendência de designar a audiência quando há litigantes raros no polo passivo (pessoas 
físicas, microempreendedores individuais, microempresas e pessoas jurídicas de pequeno porte, via de regra). A tendência de não designação aumenta à medida que o réu se torna mais habitual na justiça comum cível (é possível perceber que as razões de chance em x4 são maiores que em x3, que por sua vez, são maiores que em x2).

Das quatro variáveis obtidas na parte direita da tabela, x1 (raros) obteve alta significância, pelo que se pode concluir, com precisão, que, diante de um réu raro, as chances de se designar a audiência do art. 334 do CPC aumentam 1,92 vezes. A variável x2 (eventuais) obteve boa significância, pelo que se pode estimar que, diante de um réu eventual, as chances de a audiência vir a ser marcada diminuem 0,61 vezes. Já as variáveis x3 (contumazes) e x4 (habituais) obtiveram baixa significância, logo, o máximo que podemos extrair é a tendência de diminuição das chances de a audiência acontecer, sem que se possam cravar razões de chance (ExpB).

A análise dos dados obtidos nos permite concluir uma tendência em não designar o ato quando, no polo passivo, encontram-se litigantes mais conhecidos da justiça comum cível. Isso leva a crer que a tese - já citada em alguns trechos deste trabalho - de que os litigantes habituais já possuem estratégia processual de não transigir no início da audiência (normalmente no sentido de não conciliar no início do processo) pode estar influenciando juízes a designar menos audiências nesses casos.

Por outro lado, quando os réus são pessoas físicas ou pessoas jurídicas de porte reduzido, a ideia de que é um incômodo ser réu num processo pode levar a melhores índices de designação da audiência, uma vez que o juízes observaram (diante de seguidas situações) que há maior chance de esses réus buscarem a autocomposição ainda na fase inicial do processo.

\section{CONCLUSÕES}

No estrito ambiente dos juízes de direito das varas cíveis da comarca do Recife, a natureza do réu exerce influência sobre a escolha judicial entre o cumprimento estrito da norma processual (que determina a designação de audiência prévia) e a conduta contra legem (não marcar a audiência, contrariando a norma processual)? Os resultados da pesquisa empírica, que deu origem a este artigo, demonstram uma resposta afirmativa ao problema de pesquisa proposto.

Ao testar empiricamente a hipótese de que a variação da natureza da parte ré (entre as categorias raro, eventual, contumaz e habitual) produziria variação nas chances do juiz marcar (ou não) a audiência prévia, verificaram-se provas concretas de que, na comarca onde foi realizada a pesquisa, há uma tendência a designar a audiência quando há litigantes raros (X1) no polo passivo (pessoas físicas, microempreendedores individuais, microempresas e pessoas jurídicas de pequeno porte, via de regra) e há, no 
Para além dos fundamentos da decisão judicial: análise empírica da influência do perfil do réu sobre a decisão que dispensa as audiências obrigatórias de conciliação e mediação no início do processo (art. $334, \mathrm{CPC})$

sentido contrário, um aumento na tendência de não designação à medida que o réu se torna mais habitual (X2 a X4) na justiça comum cível da comarca de Recife/PE.

$O$ presente trabalho não se ocupou de discutir a legitimidade do juiz para dispensar a audiência do art. 334, CPC - obrigatória por força de lei - por qualquer razão relacionada à eficiência do ato ou ao interesse do réu em conciliar. Esta é outra interessante e necessária análise a se fazer, que pode ser parte de uma nova agenda de pesquisa a ser constituída a partir dos achados concretos deste trabalho.

Propusemos, aqui, verificar, por metodologia quantitativa, se o perfil do réu pode influenciar na alteração no padrão judicial de designação (ou não) da audiência, o que ficou empiricamente demonstrado. Isso nos permite avançar na compreensão (empírica) dos fatores que estão associados, ou não, às escolhas inerentes às decisões judiciais.

\section{REFERÊNCIAS}

ABELHA, Marcelo. Manual de direito processual civil. 6. ed. Rio de Janeiro: Forense, 2016.

BRASIL. Constituição Politica do Imperio do Brazil (de 25 de março de 1824). Brasília, DF: Presidência da República, 1824. Disponível em: http://www.planalto.gov.br/ccivil_03/constituicao/constituicao24.htm. Acesso em: 11 fev. 2020.

BRASIL. Lei ${ }^{\circ}$ 5.869, de 11 de janeiro de 1973. Institui o Código de Processo Civil. Brasília, DF: Presidência da República, 1973. Disponível em: http://www.planalto.gov.br/ccivil_03/leis/15869impressao.htm. Acesso em: $11 \mathrm{fev}$. 2020.

BRASIL. Lei no 13.105, de 16 de março de 2015. Código de Processo Civil. Brasília, DF: Presidência da República, 2015a. Disponível em: http://www.planalto.gov.br/ccivil_03/_ato2015-2018/2015/lei/113105.htm. Acesso em: 11 fev. 2020.

BRASIL. Lei $\mathrm{n}^{\mathrm{o}}$ 13.140, de 26 de junho de 2015. Dispõe sobre a mediação entre particulares como meio de solução de controvérsias e sobre a autocomposição de conflitos no âmbito da administração pública; altera a Lei no 9.469, de 10 de julho de 1997, e o Decreto no 70.235, de 6 de março de 1972; e revoga o $§ 2^{\circ}$ do art. $6^{\circ}$ da Lei no 9.469, de 10 de julho de 1997. Brasília, DF: Presidência da República, 2015b. Disponível em: http://www.planalto.gov.br/ccivil_03/_ato20152018/2015/lei/113140.htm. Acesso em: 11 fev. 2020.

BUARQUE, Rodrigo Costa; PEDRA, Adriano Sant'Ana. A Recusa das Partes à Audiência Preliminar no Novo Código de Processo Civil: necessidade de motivação ante 
o dever fundamental de cooperação com a justiça. Revista Magister de Direito Civil e Processo Civil, Porto Alegre, v. 72. n. 12, p. 112-123, maio/jun. 2016.

CABRAL, Trícia Navarro Xavier. A conciliação e a mediação no CPC/2015. In: CARVALHO FILHO, Antônio; SAMPAIO JÚNIOR, Herval. Os juízes e o Novo CPC. Salvador: Juspodivm, 2017.

CÂMARA, Alexandre Freitas. O novo processo civil brasileiro. 2. ed. São Paulo: Atlas, 2016.

DI SPIRITO, Marco Paulo Denucci. Hipóteses objetivas de dispensa da audiência de conciliação e mediação. 2016.2 Disponível em: https://emporiododireito.com.br/leitura/hipoteses-objetivas-de-dispensa-da-audienciade-conciliacao-e-mediacao. Acesso em: 11 fev. 2020.

GOMES NETO, José Mário Wanderley; ALVES, Catarina Bezerra. Criação das Centrais de conciliação, mediação e arbitragem em Pernambuco: uma análise de sua efetividade à luz do novo enfoque de acesso à justiça. Revista de Processo, v. 37, n. 211, p. 317-346, set. 2012.

GOMES NETO, José Mário Wanderley; BARBOSA, Luis Felipe Andrade; VIEIRA, Jorge Luiz Gonzaga. Explicando Decisões: as Aplicações da Análise por Regressão Logística (Logit) no Estudo do Comportamento Judicial. Revista de Direito Público RDU, Porto Alegre, v. 15, n. 82, 2018, p. 214-231, jul./ago. 2018.

GOUVEIA, Lúcio Grassi de. Audiência de conciliação versus audiência preliminar: a opção pela primeira e as consequências da eliminação da segunda no projeto do Novo Código de Processo Civil brasileiro (NCPC). Revista Brasileira de Direito Processual RBDPro, Belo Horizonte, a. 22, n. 85, p. 25-37, jan./mar. 2014.

LEVIN, Jack; FOX, James Alan; FORDE, David R. Elementary Statistics in Social Research. 12. ed. Upper Saddle River (EUA): Pearson, 2014.

LIMA, Evandro Souza e; PELAJO, Samantha. A mediação nas ações de família. In: ALMEIDA, Diogo Assumpção Rezende de; PANTOJA, Fernanda Medina; PELAJO, Samantha. (org.). A mediação no novo Código de Processo Civil. 2. ed. Rio de Janeiro: Forense, 2016. p. 223-244.

LIPIANI, Júlia; SIQUEIRA, Marília. Negócios jurídicos processuais sobre mediação e conciliação. In: ZANETI JUNIOR, Hermes; CABRAL, Trícia Navarro Xavier. Justiça Multiportas: mediação, conciliação, arbitragem e outros meios de solução adequada para conflitos. Salvador: JusPodivm, 2016. p. 141-167. 
Para além dos fundamentos da decisão judicial: análise empírica da influência do perfil do réu sobre a decisão que dispensa as audiências obrigatórias de conciliação e mediação no início do processo (art. $334, \mathrm{CPC})$

MARCONI, Marina de Andrade; LAKATOS, Eva Maria. Fundamentos de metodologia científica. 5. ed. São Paulo: Atlas, 2003.

MENDES, Aluisio Gonçalves de Castro; HARTMANN, Guilherme Kronemberg. A Audiência de Conciliação ou de Mediação no Novo Código de Processo Civil. Revista de Processo, v. 253, p. 163-184, mar. 2016.

MAZZOLA, Marcelo. Dispensa da audiência de conciliação/mediação: seis dribles e dois gols. Revista FONAMEC, Rio de Janeiro, v.1, n. 1, p. 253-262, maio 2017.

PALETTA, Mag Carvalho. Audiência de conciliação nos Juizados Especiais Cíveis cariocas: obstáculo ou solução? 2011. 153 f. Dissertação (Mestrado) - Curso de Direito, Fundação Getúlio Vargas, Rio de Janeiro, 2011.

PAULA FILHO, Alexandre Moura Alves de. Reforma processual e argumentação contra legem: quais fatores influenciam os juízos das varas cíveis de Recife/PE a não designarem a audiência prevista no art. 334 do CPC? 2020. 144 p. Dissertação (Mestrado em Direito) - Universidade Católica de Pernambuco, Pernambuco, 2020.

PERNAMBUCO. Tribunal Regional Federal da 5a Região. Estatística dos Centros de Conciliação da 5a Região - Ano 2019 (CEJUSC/Recife). 2019. Disponível em: https://www.trf5.jus.br/index.php?option=com_phocadownload\&view=category\&dow nload=9557:estatistica-mensal-do-cejusc-recife-pe-18092019\&id=190:conciliacao. Acesso em: 5 jan. 2020.

POLLONI, Juliana. A necessária mudança de paradigma sobre a experiência do consumidor na resolução de conflitos para fidelização da clientela. In: RODAS, João Grandino et al. (coord.). Visão Multidisciplinar das Soluções de Conflitos no Brasil. Curitiba: Editora Prismas, 2018. p. 87-98.

REDONDO, Bruno Garcia. Conciliação e mediação. In: ALVIM, Teresa Arruda (coord.). CPC em foco - temas essenciais e sua receptividade: dois anos de vigência do novo CPC. 2. ed. São Paulo: Thomson Reuters, 2018.

STRECK, Lenio Luiz. Uma ADC contra a decisão no HC 126.292 - sinuca de bico para o STF! Consultor Jurídico, 29 fev. 2016. Disponível em: https://www.conjur.com.br/2016-fev-29/streck-adc-decisao-hc-126292-sinuca-stf. Acesso em: 11 dez. 2019.

TARTUCE, Fernanda. Mediação nos conflitos civis. 4. ed. Rio de Janeiro: Forense; São Paulo: Método, 2018.

VASCONCELOS, Carlos Eduardo de. Mediação de conflitos e práticas restaurativas. 4. ed. Rio de Janeiro: Forense; São Paulo: Método, 2015. 
VENTURI, Elton. Transação de direitos indisponíveis? In: ZANETI JUNIOR, Hermes, CABRAL, Trícia Navarro Xavier. Justiça Multiportas: mediação, conciliação, arbitragem e outros meios de solução adequada para conflitos. Salvador: Juspodivm, 2016. p. 405 429.

\section{NOTA}

Declaramos que o artigo intitulado "PARA ALÉM DOS FUNDAMENTOS DA DECISÃO JUDICIAL: ANÁLISE EMPÍRICA DA INFLUÊNCIA DO PERFIL DO RÉU SOBRE A DECISÃO QUE DISPENSA AS AUDIÊNCIAS OBRIGATÓRIAS DE CONCILIAÇÃO E MEDIAÇÃO NO INÍCIO DO PROCESSO (ART. 334, CPC)", submetido à Revista Opinião Jurídica, representa fruto direto das pesquisas desenvolvidas pelos autores no Programa de Pós-graduação em Direito da Universidade Católica de Pernambuco (grupo de pesquisa: uData), tendo ambos realizado concomitantemente as tarefas de seu planejamento, execução e revisão da seguinte forma: 1) Alexandre Moura Alves de Paula Filho: desenvolveu o referencial teórico acerca do modelo de audiências previsto no art. 334, CPC e, no âmbito da pesquisa empírica, coletou e tabulou os dados dos processos analisados; 2) José Mário Wanderley Gomes Neto: realizou a análise por regressão logística dos dados colhidos, fazendo a interpretação dos resultados obtidos na logit, além de revisão textual da parte teórica do artigo, redigida inicialmente pelo seu coautor.

\section{Como citar este documento:}

PAUlA FILHO, Alexandre Moura Alves de; GOMES NETO, José Mário Wanderley. Para além dos fundamentos da decisão judicial: análise empírica da influência do perfil do réu sobre a decisão que dispensa as audiências obrigatórias de conciliação e mediação no início do processo (art. 334, CPC). Revista Opinião Jurídica, Fortaleza, v. 19, n. 31, p. 127-153, maio/ago. 2021. 